\title{
Effect of Different Priming Methods on Nodulation in Blackgram (Vigna mungo L.) Seeds
}

\author{
Vijay Dugesar*, A.K. Chaurasia, Bineeta M. Bara and Kamal Kant \\ Department of Genetics and Plant Breeding, Naini Agricultural Institute, Sam Higginbottom \\ University of Agriculture, Technology and Sciences, Allahabad, 211007 U.P., India \\ *Corresponding author
}

\section{A B S T R A C T}

\begin{tabular}{|l|}
\hline Ke e y w o r d s \\
Blackgram, \\
Priming methods, \\
Nodulation, \\
PEG6000, CaCl2, \\
NaCl, Tulsi and \\
Curi leaf extract. \\
\hline Article Info \\
\hline $\begin{array}{l}\text { Accepted: } \\
\text { 17 June } 2017 \\
\text { Available Online: } \\
\text { 10 July } 2017\end{array}$ \\
\hline \hline
\end{tabular}

The experiment was conducted in Field Experimentation Centre, Department of Genetics and Plant Breeding, Sam Higginbottom University of Agriculture, Technology and Sciences, Allahabad (U.P.) during kharif season 2016, in order to standardize the best method of priming specific to Blackgram (var. PU-31). Four methods of priming viz., hydropriming, osmopriming, halopriming, and organic priming with control (Unprimed) were evaluated by screening 12 hour duration and different concentrations viz., $\mathrm{T}_{0^{-}}$ Unprimed (Control), hydropriming - $\mathrm{T}_{1}$-Distilled water (hydration), osmopriming- $\mathrm{T}_{2^{-}}$ Polyethylene Glycol $\left(\mathrm{PEG}_{6000}\right)$ 20\%, halopriming- $\mathrm{T}_{3}$-Sodium Chloride $(\mathrm{NaCl}) 1 \%, \mathrm{~T}_{4}-$ Calcium Chloride $\left(\mathrm{CaCl}_{2}\right) 1 \%$, organic priming- $\mathrm{T}_{5}$-Tulsi leaf extract $(5 \%), \mathrm{T}_{6}$-Curi leaf extract (5\%). It was found that all the priming treatment showed significance difference with the control and the highest field emergence per cent and plant nodulation characters were observed for $\mathrm{PEG}_{6000}$ priming. Highest nodulation was observed in PEG and $\mathrm{CaCl}_{2}$. Seed priming, its simplicity and no requirement for expensive equipment and chemical could be used as a simple method for overcoming related to a poor germination and seedling establishment and helps in sustaining agriculture and cost effective and economic, non-toxic and eco-friendly sources.

\section{Introduction}

Pulses have been in focus in recent times due to the continuous upswing in their prices. Stagnant productivity coupled with declining availability has created substantial demand supply gap, forcing heavy import bill on the exchequer and affecting nutritional security of majority of the population for whom pulses are the one of the cheapest sources of protein. Besides serving as an important source of protein for a large portion of the global population, pulses contribute to healthy soils and climate change mitigation through their nitrogen-fixing properties (Mohanty and Satyasai, 2015). Pulses constitute an important ingredient in predominantly vegetarian diet and are important source of protein that nutritionally balances the protein requirement of vegetarian population. They supply minerals and vitamins and provide an abundance of food energy. Pulses provide a cheaper source of nutrients/proteins as they generally contain nearly twice as much as protein as that of cereals and hence correctly called poor man's meat.

Pulses are also important for sustainable agriculture enriching the soil through biological nitrogen fixation, fixes about 40-50 
$\mathrm{kg}$ of N/ha (Hariprasanna and Bhatt, 2002). Blackgram (Vigna mungo L.) is an important nutritious pulse crop occupying unique position in Indian Agriculture, belongs to family Leguminoseae with chromosome number 2n=2x=22 (Malik, 1994).

Black gram is a third most important pulse crop of India representing $15 \%$ of the total pulse area and 9\% total pulse production. Black gram gives low seed yield mainly due to poor management and low soil fertility. Nitrogen due to leaching and volatilization and phosphorous due to fixation may not be available adequately at flowering and pod formation stages of crop and result in shedding flowers and pods (Hamid, 1988). Blackgram crop is one of the important pulse crops, grown throughout the century. In belongs to the family Leguminoceae and subfamily Papilionaceae. It is also cultivated in many other tropical and sub - tropical countries of the world, It is commonly known as urdbean. The crop is resistant to adverse climatic conditions and improves the soil fertility by fixing atmospheric nitrogen in the soils. It has been reported that the crop produces equivalent to $22.10 \mathrm{~kg} \mathrm{~N}$ ha- 1 which has been estimated to be supplement of 59 thousand tones urea annually. The pulse, black gram plays an important role in India diet. It contains vegetable protein and supplement to cereal based diet, it contains about $26 \%$ protein, which is almost three times that of cereals and other minerals and vitamins. Besides, it is also used as nutritive fodder, especially for mulch animals.

Priming is the method used to improve stand establishment in several crops. Seed priming is a process in which seeds are imbibed either in water or in osmotic solution or combination of solid matrix carrier and water in specific proportion followed by drying before radical emergence. The theory of seed priming was proposed by Heydecker in 1973. Seed priming is an effective technology to enhance rapid and uniform emergence and to achieve high vigour, leading to better stand establishment and yield (Harris et al., 2007). Halopriming was conducted with salt $\mathrm{NaCl}$ $1 \%$ solution and $\mathrm{CaCl}_{2} \quad 1 \%$ solution concentration. Seeds were soaked $25^{\circ} \mathrm{C}$ for 14 hour in Petri plates. After dried and at room temperature and subjected to germination test, done at $25^{\circ} \mathrm{C}$ for $14 \mathrm{hrs}$. Evaluated the effects of $\mathrm{NaCl}$ priming with $\mathrm{KNO}_{3}$ on the germination traits and seedling growth of four Helianthus annuus L. cultivars under salinity conditions and reported that germination percentage of primed seeds was greater than that of un-primed seeds Bajehbaj, (2010). Seed priming has presented promising, and even surprising results, for many seeds including the cereal seeds Bradford, (1986). In which organic priming plant extract is used after that drying, such as Neem leaf extract, Curi leaf extract, Tulsi leaf extract, neem seed kernel powder for maize. A higher concentration of this powder $(10 \% \mathrm{w} / \mathrm{w})$ was found effective over long period of time Sharma (1995).

\section{Materials and Methods}

The experiment was conducted in Field Experimentation Centre, Department of Genetics and Plant Breeding, Sam Higginbottom University of Agriculture, Technology and Sciences, Allahabad (U.P.) during kharif season 2016, in order to standardize the best method of priming specific to Blackgram (var. PU-31). The treatments used at different concentrations for priming were $\mathrm{T}_{0}$-Unprimed (Control), $\mathrm{T}_{1^{-}}$ Distilled water, $\mathrm{T}_{2^{-}}$Polyethylene Glycol $\left(\mathrm{PEG}_{6000}\right) 20 \%, \mathrm{~T}_{3}$-Sodium Chloride $(\mathrm{NaCl})$ $1 \%, \mathrm{~T}_{4}-$ Calcium Chloride $\left(\mathrm{CaCl}_{2}\right) 1 \%, \mathrm{~T}_{5^{-}}$ Tulsi Leaf Extract 5\% and $\mathrm{T}_{6}$-Curi Leaf Extract 5\%. After cleaning and grading, the seeds were soaked in respective priming solutions at different volume of seeds for 
twelve hours. Then the seeds were air dried under the shade to bring back to their original moisture content and used for sowing on field.

\section{Preparation of solutions}

For the preparation of solution one gram of each chemical was taken in a beaker. These chemicals were added separately in $1000 \mathrm{ml}$. of distilled water with constant stirring. The volume of solution will finally constituted to one litter, then it become 1000 ppm stock solution of each chemical.

The flasks containing chemicals was covered with muslin cloth to avoid any contamination. For the preparation of $\mathrm{PEG}_{6000}(20 \%)$ solution 200 (g) PEG was a taken in a measuring flask made up to $1000 \mathrm{ml}$. distilled water, while for $\mathrm{NaCl}(1 \%)$ solution $10(\mathrm{~g}), \mathrm{CaCl}_{2} \quad(1 \%)$ solution $10(\mathrm{~g})$, Tulsi leaf extract $(5 \%)$ solution $50(\mathrm{gm})$ and Curi leaf extract $(5 \%)$ solution $50(\mathrm{gm})$ was taken in a measuring flask and made up to $1000 \mathrm{ml}$ with distilled water.

\section{Preparation of plant leaf extract}

The fresh leaves of the tulsi and curi plants were collected separately and dried in shade. The shade dried leaves were powdered using mortar and pestle. Then exactly weigh fifty gram of leaf powder using weighing balance and dissolved in $100 \mathrm{ml}$. of distilled water which was measured already in the beaker to make 5\% leaf extract. The leaf extract was filtered by using muslin cloth to remove unwanted material and leaf debris.

Randomized Block Design (RBD) (Panse and Sukhatme, 1967) with three replications was performed. Observations on field viz., field emergence and nodulation characters were worked out and the data was statistically analyzed using ANOVA.
Number of seedling emerged on $15^{\text {th }}$ days Field emergence $(\%)=$

Total no. of seeds sown

One hundred seeds from each treatment in four replications were used for field emergence studies. The seeds were sown in well prepared soil at $3 \mathrm{~cm}$ deep. The field emergence count was taken on the $15^{\text {th }}$ day after sowing and the emergence percentage was calculated taking into account the number of seedlings emerged three centimeter above the $s$

\section{Number of nodules per plant}

Ten plants from each treatment plot in three replication were uprooted 30 and 45 days after seeding (DAS), and the extent of nodulation was estimated by carefully washing the roots and detaching the nodules before counting (Khan et al., 2006).

\section{Nodules fresh weight}

After washing the root nodules from the field the nodules were detached from the plant roots and weighed in an electronic weigh balance for fresh weight of root nodules expressed in milligrams (mg).

\section{Nodules dry weight}

After taking the fresh weight the root nodules they are kept in butter paper and kept in oven for drying at $80^{\circ} \mathrm{C}$ for $24 \mathrm{hrs}$ and then weighed for dry weight of nodules expressed in milligrams (mg) (Khan et al., 2006).

\section{Results and Discussion}

According to the results, all studied traits were affected by the treatments and there was completely significant difference between control (non-primed seeds) and primed seeds (Table 1). Field emergence and nodulation 
characters viz., Field emergence per cent, Number of nodules per plant, Nodules fresh weight $(\mathrm{mg})$, Nodules dry weight $(\mathrm{mg})$ were affected by $\mathrm{PEG}_{6000} 20 \%$ concentration significantly recorded maximum where found in lowest control (Table 2).

Osmopriming with PEG $\left(\mathrm{T}_{2}\right)$ recorded maximum field emergence per cent $(82.67 \%)$ followed by halopriming with $\mathrm{CaCl}_{2} \quad\left(\mathrm{~T}_{4}\right)$ $(81.67 \%)$ where found in lowest control $\left(\mathrm{T}_{0}\right)$ $(75.33 \%)$. The interaction effect on emergence percentage is statistically significant Nagar et al., (1998). Hussian et al., (2014) states that Priming is one of the physiological ways which enhances performance of seed and seeds show rapid and synchronized germination and also show the importance of seed vigor and role of seed enhancement treatments in abiotic stress tolerance.

Osmopriming with PEG $\left(\mathrm{T}_{2}\right)$ was observed numerically in maximum numbers of nodules (24.00) and (33.00) followed by halopriming with $\mathrm{CaCl}_{2}\left(\mathrm{~T}_{4}\right)$ (21.67) and (32.00) 30 and 45 DAS respectively. Unprimed plants produced lowest nodules (16.33) and (27.00) with 30 and 45 DAS respectively. Treatments $T_{2}, T_{4}$ are statistically on par with each other for number of nodules per plant at 30 and 45
DAS. The interaction effect of priming methods on number of nodules per plant at 30 and 45 DAS was found to be significant. Premartne and Oertli (1994) reported that dry matter yield, nodule number, fresh weight of nodule per plant, average weight of nodule and the total nitrogen accumulation increased in soya bean when the seeds were primed with potassium at $5.0 \mathrm{mM}$ concentration but the nitrogenase activity remains unaltered.

Data on nodule fresh weight per plant was found significant, osmopriming with PEG $\left(\mathrm{T}_{2}\right)$ was observed with maximum fresh weight $(135.00 \mathrm{mg})$ and $(224.33 \mathrm{mg})$ followed by halopriming with $\mathrm{CaCl}_{2}\left(\mathrm{~T}_{4}\right)$ (132.67) and (220.00) 30 and 45 DAS respectively. Lowest fresh weight observed with unprimed $\left(\mathrm{T}_{0}\right)(123.67 \mathrm{mg})$ and $(191.33$ $\mathrm{mg}) 30$ and 45 DAS respectively. The interaction effect of priming methods on nodule fresh weight per plant at 30 and 45 DAS was also significant. Singh and Kataria (2012) studied the role of potassium on nitrogen fixation in alleviating water stress in chick pea and concluded that there was a corresponding increase in nitrogen fixation and its attributes with the increase in the potassium level.

Table.1 Analysis of variance for 7 plant nodule characters in blackgram

\begin{tabular}{|c|l|c|c|c|}
\hline \multirow{2}{*}{ S.No. } & \multicolumn{1}{|c|}{ Characters } & \multicolumn{2}{|c|}{ Mean sum of squares } \\
\cline { 3 - 5 } & & $\begin{array}{c}\text { Replications } \\
(\mathbf{d f = 2})\end{array}$ & $\begin{array}{c}\text { Treatment } \\
\mathbf{S}(\mathbf{d f = 6})\end{array}$ & $\begin{array}{c}\text { Error } \\
(\mathbf{d f = 1 2})\end{array}$ \\
\hline 1. & Field Emergence Per cent & $10.43^{* * *}$ & $22.19^{* * *}$ & 2.43 \\
\hline 2. & No. of Nodules per plant at 30 DAS & $11.62^{* * *}$ & $20.08^{* * *}$ & 1.84 \\
\hline 3. & No. of Nodules per plant at 45 DAS & $15.76^{* * *}$ & $12.83^{* * *}$ & 1.87 \\
\hline 4. & Nodules Fresh Weight at 30 DAS & $176.19^{* * *}$ & $50.56^{* * *}$ & 12.91 \\
\hline 5. & Nodules Fresh Weight at 45 DAS & $163.62^{* * *}$ & $438.98^{* * *}$ & 38.17 \\
\hline 6. & Nodules Dry Weight at 30 DAS & $22.05^{* * *}$ & $29.19^{* * *}$ & 3.38 \\
\hline 7. & Nodules Dry Weight at 45 DAS & $37.90^{* * *}$ & $61.27^{* * *}$ & 5.29 \\
\hline
\end{tabular}

** Significant at 5\% level of significance 
Table. 2 Mean performance of blackgram for 7 plant nodule characters

\begin{tabular}{|c|c|c|c|c|c|c|c|c|}
\hline $\begin{array}{l}\dot{z} \\
\dot{s}\end{array}$ & 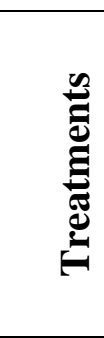 & 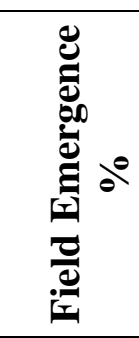 & 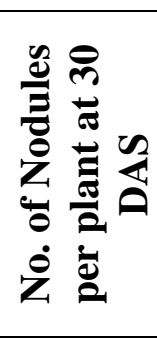 & 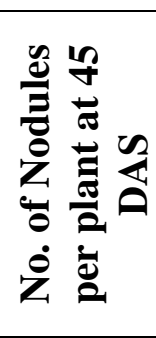 & 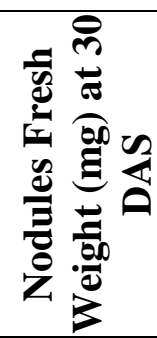 & 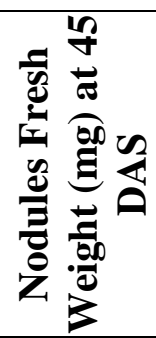 & 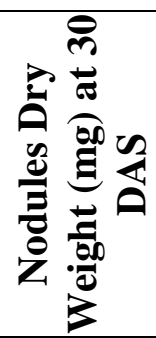 & 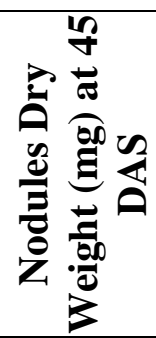 \\
\hline 1 & $\mathbf{T}_{\mathbf{0}}$ & 75.33 & 16.33 & 27.00 & 123.67 & 191.33 & 17.33 & 31.33 \\
\hline 2 & $T_{1}$ & 76.67 & 17.67 & 28.33 & 125.00 & 196.67 & 19.67 & 34.67 \\
\hline 3 & $\mathbf{T}_{2}$ & 82.67 & 24.00 & 33.00 & 135.00 & 224.33 & 27.00 & 45.00 \\
\hline 4 & $T_{3}$ & 80.33 & 20.33 & 30.67 & 128.33 & 207.33 & 22.00 & 38.67 \\
\hline 5 & $\mathbf{T}_{4}$ & 81.67 & 21.67 & 32.00 & 132.67 & 220.00 & 24.00 & 41.33 \\
\hline 6 & $\mathbf{T}_{5}$ & 78.33 & 18.33 & 29.93 & 126.33 & 201.00 & 20.67 & 35.67 \\
\hline 7 & $T_{6}$ & 81.00 & 20.00 & 30.00 & 129.67 & 211.67 & 22.67 & 39.00 \\
\hline \multicolumn{2}{|c|}{ Grand Mean } & 79.43 & 19.76 & 30.05 & 128.67 & 207.48 & 21.90 & 37.95 \\
\hline \multicolumn{2}{|c|}{ C.D. (5\%) } & 2.77 & 2.41 & 2.43 & 6.39 & 10.99 & 3.27 & 4.09 \\
\hline \multicolumn{2}{|c|}{$\mathrm{SE}(\mathrm{m})$} & 0.90 & 0.78 & 0.79 & 2.07 & 3.57 & 1.06 & 1.33 \\
\hline \multicolumn{2}{|c|}{ C.V. } & 1.96 & 6.87 & 4.55 & 2.79 & 2.98 & 8.39 & 6.06 \\
\hline
\end{tabular}

Osmopriming with PEG $\left(\mathrm{T}_{2}\right)$ was observed maximum nodule dry weight per plant $(27.00$ $\mathrm{mg}$ ) and $(45.00 \mathrm{mg})$ followed by halopriming with $\mathrm{CaCl}_{2}\left(\mathrm{~T}_{4}\right)(24.00 \mathrm{mg})$ and $(41.33 \mathrm{mg}) 30$ and 45 DAS respectively. Lowest dry weight observed with control $\left(\mathrm{T}_{0}\right)(17.33 \mathrm{mg})$ and $(31.33 \mathrm{mg}) 30$ and 45 DAS respectively.

The interaction effect of priming methods and duration on nodule dry weight per plant at 30 DAS was found to be significant. George et al., (2014) revealed the vital roles played by rhizobial inoculants supplemented with phosphorus and potassium has constructive effect in improving photosynthesis, nutrient uptake, nodulation, growth, yield and economic benefits in legumes.

Showed that interaction between seed priming media $\mathrm{x}$ cultivar $\mathrm{x}$ temperature and seed priming media $\mathrm{x}$ cultivar $\mathrm{x}$ priming duration have the beneficial effects on germination index, speed of germination, dry weight and seedling height Yari et al., (2010)
The effect of priming method found to be significant in all the nodule parameters. Significant differences in all the nodule observations were observed due to different priming methods. Among different priming methods, seeds osmoprimed with $\mathrm{PEG}_{6000}$ recorded maximum per cent of field emergence $(82.67 \%)$ followed by haloprimed $\left(\mathrm{CaCl}_{2}\right)$ seeds $(81.67 \%)$ and found to be lowest in unprimed (control) seeds (75.33\%).

Number of nodules per plant (24 and 33) were highest in osmoprimed $\left(\mathrm{PEG}_{6000}\right)$ seeds and lowest in unprimed (control) seeds (16.33 and 27.00) 30 and 45 DAS respectively. Nodule fresh weight was highest observed in plots having seeds primed with $\mathrm{PEG}_{6000}$ (osmoprimed) (135 mg and $224.33 \mathrm{mg}$ ) and lowest in unprimed (control) seeds (123.67 $\mathrm{mg}$ and $191.33 \mathrm{mg}$ ) 30 and 45 DAS respectively. Nodules dry weight was observed to be higher in $\mathrm{PEG}_{6000}$ primed seeds $(27 \mathrm{mg}$ and $45 \mathrm{mg}$ ) and found to be lowest in unprimed (control) seeds (17.33 and 31.33) 30 and 45 DAS respectively. 
In conclusion, Priming increases the nodulation of blackgram seeds, significantly in field condition. osmopriming (PEG), Halopriming $\left(\mathrm{CaCl}_{2}\right)$ significantly increased the nodulation of blackgram. Osmopriming with PEG showed maximum increase in nodulation. Priming of the blackgram seeds for $12 \mathrm{hrs}$, in which PEG best result to enhanced nodulation. These conclusions are based on the results of six months investigation and therefore further investigation is needed to arrive at valid recommendations.

\section{Acknowledgement}

The author are thankful to the Hon'ble Vice Chancellor, HOD, Advisor and non-Teaching staff Department of Genetics and Plant Breeding, Sam Higginbottom University of Agriculture, Technology and Science Allahabad, U. P., for providing all necessary facilities and support.

\section{References}

Bajehbaj AA. (2010). The effects of $\mathrm{NaCl}$ priming on salt Tolerance in Sunflower Germination and Seedling grown under salinity conditions. African Journal of Biotechnology 9 (12), 1764-1770.

Bradford K.J. (1986). Manipulation of seeds water relation via osmotic priming to improve germination under stress condition. Horticulture science, 59(2):672-676.

George, W., Mmbaga, Kelvin, M., Mtei, Patrick, A. Ndalddemi. (2014). Extrapolations on the Use of Rhizobium Inoculants Supplemented with Phosphorus (P) and Potassium (K) on Growth and Nutrition of Legumes. Agricultural Sciences, 5: 1207-1226.

Hamid, A. (1988). Nitrogen and Carbofuran effect on the growth and yield performance of mungbean. Journal of
Agronomy and Crop Science.161 (1):11-16.

Hariprasanna, K and Bhatt, J. (2002). Pulse production looking at constraints and prospects. Agriculture today, Aug, 4953.

Harris D, Rashid A, Miraj G, Arif M, (Shah H. 2007). 'On-farm' seed priming with zinc sulphate solution-A cost-effective way to increase the maize yields of resource poor farmers. Field Crops Res. 102 119-127.

Heydecker, W. (1973). Accelerated germination by osmotic seed treatment. Nature.246: 42-44.

Hussian, I., Ahmad, R., Farooq, M., Rehman, A., Amin, M and Bakar, M. A. (2014). Seed priming: a tool to invigorate the seeds. ScientiaAgriculturae, 7 (3):122128.

Khan, M. S., Chaudhry, P., Wani, P. A., Zaidi, A. (2006). Biotoxic effects of the herbicides on growth, seed yield, and grain protein of greengram (Vigna radiata L.). Journal of Applied Sciences and Environmental Management, 10 (3): 141- 146.

Malik, B.A. (1994). Grain Legumes.In: Nazir, M.S. (ed.), Crop Production. p. 301. National Book Foundation, Islamabad.

Mohanty,S. and Satyasai,K.J. (2015). Feeling the pulse, Indian pulses sector. NABARD Rural Pulses, Issue X- JulyAugust 2015.

Nagar, R. P., Dadlani, M. and Sharma, S. P. (1998). Effect of hydropriming on field emergence and crop growth of maize genotypes. Seed Science Research, 26: 1-5.

Panse, V.G. and Sukhatme, P.V. (1967). Statistical methods for agricultural workers $\left(2^{\text {nd }}\right.$ ED.) ICAR Publication, New Delhi.

Premartne, K. P. and Oertli, J. J., (1994). The influence of potassium supply on nodulation, nitrogenase activity and 
nitrogen accumulation of soybean growth in nutrient solution. Fertilizer research.35: 95-99.

Sharma, R. IC. (1995). Neem leaf powder and cobash against Rhyzopertha dominica (F), in stored maize. Indian Journal of Entomology, 57:15-17.

Singh, N. and Kataria, N. (2012). Role of potassium fertilizer on nitrogen fixation in Chickpea (Cicer arietinum L.) under quantified water stress. Journal of Agricultural Technology, 8(1): 377-392. 2012.

Yari, L., Aghaalikani, M. and Khazaei, F. (2010). Effect of seed priming duration and temperature on seed germination behaviour of bread wheat (Triticum aestivum L.). ARPN J AgricBiolSci, 5: 1.

\section{How to cite this article:}

Vijay Dugesar, A.K. Chaurasia, Bineeta M. Bara and Kamal Kant. 2017. Effect of Different Priming Methods on Nodulation in Blackgram (Vigna mungo L.) Seeds. Int.J.Curr.Microbiol.App.Sci. 6(7): 1137-1143. doi: https://doi.org/10.20546/ijcmas.2017.607.138 